\title{
Divergent Pathways for Reactions of 3-Formylchromone with Cyclic Secondary Amines in Alcoholic Media
}

\author{
Kirill S. Korzhenko \\ Dmitry V. Osipov \\ Vitaly A. Osyanin* \\ Yuri N. Klimochkin
}

Department of Organic Chemistry, Samara State Technical University, 244 Molodogvardeyskaya St., 443100 Samara, Russian Federation

VOsyanin@mail.ru

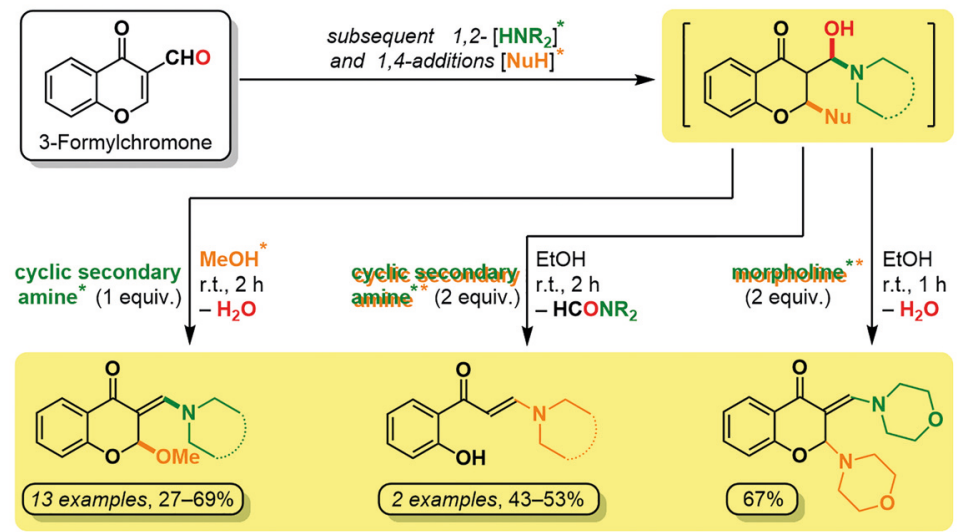

Received: 27.11.2019

Accepted: 28.11 .2019

Published online: 11.12 .2019

DOI: 10.1055/s-0039-1690339; Art ID: so-2019-d0034-I

License terms: CC $(\$$

(c) 2019. The Author(s). This is an open access article published by Thieme under the terms of the Creative Commons Attribution-NonDerivative-NonCommercial-License, permitting copying and reproduction so long as the original work is given appropriate credit. Contents may not be used for commercial purposes or adapted, remixed, transformed or built upon. (https://creativecommons.org/licenses/by-nc-nd/4.0/)

Abstract Reaction of 3-formylchromone with cyclic secondary amines in methanol results in (E)-2-methoxy-3-( $\mathrm{R}_{2} \mathrm{~N}$-methylene)chroman-4ones, while use of ethanol leads to $(E)$-2-morpholino-3-(morpholinomethylene)chroman-4-one or enaminoketones as dihydropyran ringopening products. The solubility of the formed products in alcoholic media is postulated to be a key factor that determines the reaction pathway.

Key words 3-formylchromone, 4-chromanone, cyclic secondary amines, Michael reaction, enamino ketones, $1 \mathrm{H}$-azoles

Chromones, ${ }^{1}$ including flavones, and related chroman4-ones ${ }^{2}$ generate interest in medicinal chemistry by reason of the widespread existence of these structure units among natural products and synthetic medicines. ${ }^{1,3}$ 4-Oxo-4Hchromene-3-carbaldehyde $\mathbf{1}$ (Scheme 1; more commonly known as 3-formylchromone) can be distinguished from the array of chromone derivatives due to the presence of three nonequivalent electrophilic centers (an aldehyde, C-2 and $\mathrm{C}-4$ carbons) and a system of conjugated bonds in its structure, that makes 3-formylchromone an attractive pre- cursor with variable reactivity for the synthesis of complex molecules in the reactions with Michael donors, dienes and dienophiles. ${ }^{4}$ Several examples of reactions of 3-formylchromones with primary aryl- and hetarylamines, which lead to a wide range of products, have been described. ${ }^{5}$ However, their reactions with secondary amines, including saturated heterocycles, have been significantly less examined. It is known that the reaction of 3-formylchromones with pyrrolidine, $\mathrm{N}$-methylpiperazine or piperidine in ethanol leads to enaminoketones $2 .{ }^{6}$ Most likely, the mechanism includes the formation of an unstable Michael adduct followed by deformylation and ring opening under action of the second equivalent of the base (Scheme 1 ).

We have found that the reaction of stoichiometric amounts of 3-formylchromone $\mathbf{1}$ and cyclic secondary amines, such as morpholine, pyrrolidine, substituted piperidines and piperazines, in methanol at room temperature produces (E)-2-methoxy-3-( $\mathrm{R}_{2} \mathrm{~N}$-methylene $)$ chroman-4ones 3a-m in $27-69 \%$ yield (Scheme 2$).{ }^{7}$ It should be noted that the reason we succeeded in obtaining 2-methoxychroman-4-ones 3 can be ascribed to their poor solubility in methanol, which leads to their crystallization from the reaction medium and shifts the equilibrium towards these products. Indeed, we were not able to isolate 2-methoxychroman-4-ones, which have good solubility. Thus, attempts to obtain 2-methoxychroman-4-ones with piperidine, 4-hydroxypiperidine, piperidin-4-one, $N$-methylpiperazine and 2-(piperazin-1-yl)ethan-1-ol moieties were

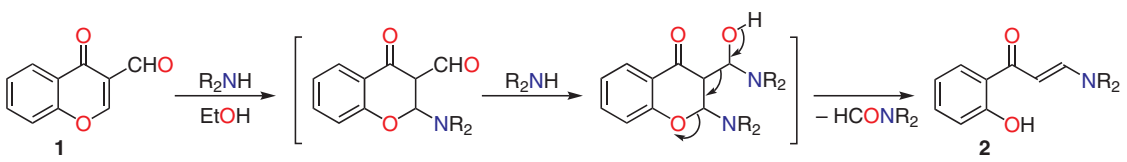

Scheme 1 Synthesis of enaminoketones 2 from 3-formylchromone 1 and secondary amines 
unsuccessful due to lack of crystallization of the desired products and, as a consequence, formation of a complex mixture of unidentified compounds. In this case, the question naturally arises as to whether the reaction is specific for cyclic secondary amines. In the reaction of 3-formylchromone 1 and diethylamine or dibenzylamine, we also obtained complex mixtures of unidentified products. Therefore, we postulate that the presence of a nucleophilic nitrogen in a ring is necessary for success of the reaction. The 2-methoxychroman-4-ones cannot be purified by column chromatography due to their decomposition on silica gel.

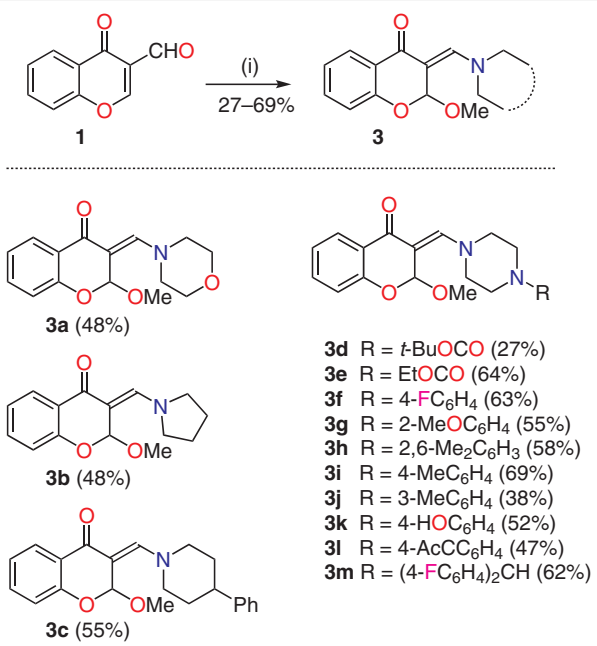

Scheme 2 Synthesis of 3a-m. Reagents and conditions: (i) $\mathbf{1}$ (1 mmol), cyclic secondary amine ( $1 \mathrm{mmol}), \mathrm{MeOH}(3 \mathrm{~mL})$, r.t., 2 h.

All substituted 2-methoxychroman-4-ones 3 were obtained as individual $(E)$-isomers. A NOESY spectrum of compound 3a showed correlations between $\mathrm{H}-2$ and $\mathrm{CH}_{2} \mathrm{~N}$ and the absence of interaction between $\mathrm{H}-2$ and $=\mathrm{CHN}$ protons, which confirms the trans arrangement of the carbonyl group and the morpholine fragment. The ${ }^{1} \mathrm{H}$ NMR spectra of chromanones 3 contain distinctive singlets at 3.28-3.45, 6.00-6.19 and 7.54-7.81 ppm for methoxy, $\mathrm{H}-2$ and $=\mathrm{CHN}$ protons, respectively. Distinguishing resonances at 54.5$54.9 \mathrm{ppm}$ for the methoxy-carbon, at 99.0-99.4 ppm for C2 , at $100.4-101.7 \mathrm{ppm}$ for C-3, at $147.5-150.3 \mathrm{ppm}$ for $=\mathrm{CHN}$, at $156.2 \mathrm{ppm}$ for C $-8 \mathrm{a}$, and $177.4-179.5 \mathrm{ppm}$ for the carbonyl carbon were observed in the ${ }^{13} \mathrm{C}$ NMR spectra. The IR spectra of compounds 3 contain a high intensity band corresponding to the carbonyl group at $1630-1657 \mathrm{~cm}^{-1}$.

One of the possible ways for further transformation of the obtained chroman-4-ones $\mathbf{3}$ is their use as heterodienes in a Diels-Alder reaction. In particular, the reaction of closely related 2-unsubstituted chroman-4-ones with in situ generated dichloroketene or phenylchloroketene, leading to formation of 4-amino-3,4-dihydro- $2 \mathrm{H}, 5 \mathrm{H}$-pyrano$[3,2-c]$ chromen-2-ones has been previously described. ${ }^{8}$ It is known that 3-formylchromone $\mathbf{1}$ can act as a heterodiene through the involvement of the enal system, ${ }^{9}$ while its reaction with amines blocks the enal and switches the crossconjugated carbonyl moiety for hetero-Diels-Alder reactions.

At the same time, the reaction of the 3-formylchromone with 2 equivalents of morpholine in ethanol at room temperature or in refluxing benzene leads to 2-morpholino-3(morpholinomethylene)chroman-4-one (4; Scheme 3) with (E)-configuration, which was confirmed by single-crystal Xray structural analysis. ${ }^{10}$ Moreover, a NOESY spectrum showed an interaction between the $\mathrm{H}-2$ proton and $\mathrm{CH}_{2} \mathrm{~N}$ protons of both morpholine rings, while an interaction between the protons of $\mathrm{H}-2$ and $=\mathrm{CHN}$ unit is absent. On the other hand, in the reaction with 2 equivalents of pyrrolidine or 1-(4-fluorophenyl)piperazine, only enaminoketones $\mathbf{2 a}$ and $\mathbf{2} \mathbf{b}$ were isolated under the same conditions. ${ }^{7}$

It should be noted that the formation of related chroman-4-one compounds 3 as $(Z)$-isomers from 3-formylchromones in various alcohols has been previously described for primary aromatic amines exclusively..$^{11}$ This fact can be explained by the stabilization of the resulting products by intramolecular hydrogen bonding, while such stabilization in the obtained products $\mathbf{3 a -} \mathbf{\mathbf { m }}$ is absent (Scheme 4 ). The first stage of the reaction of 3-formylchromone with amines may be either conjugate addition or 1,2-addition to the aldehyde group. It was shown that, in the case of aromatic primary amines, the reaction takes the first pathway. ${ }^{5 \mathrm{a}, 12 \mathrm{f}}$ In this case, the driving force of the process is the formation of an intramolecular hydrogen bond between the $\mathrm{NH}$ group and the oxygen atom of the pyranone carbonyl group. However, conjugate addition of 1,2,4-triazoles and benzotriazoles to 3-formylchromone would lead to Michael adducts that are not stabilized by hydrogen bonding. Therefore, the reaction proceeds via 1,2-addition, which was con-



Scheme 3 Synthesis of $\mathbf{2 a}$, $\mathbf{2 b}$ and $\mathbf{4}$. Reagents and conditions: (i) 1 ( $2 \mathrm{mmol})$, morpholine (4 mmol), EtOH (5.5 mL), r.t., 1 h; (ii) 1 (1 mmol), pyrrolidine or 1-(4-fluorophenyl)piperazine ( $2 \mathrm{mmol})$, EtOH (3 mL), r.t., $2 \mathrm{~h}$. 




Scheme 4 Principal transformations of 3-formylchromone $\mathbf{1}$ with amines in alcohol media

firmed by isolation of the corresponding 3-[hydroxy(azol1-yl)methyl]chromen-4-ones. ${ }^{12}$ We believe that, in the case of cyclic secondary amines, the reaction also initially proceeds via 1,2-addition to the aldehyde group with the formation of geminal amino alcohols $\mathbf{A}$, which are further converted into adducts B due to nucleophilic attack on the C-2 carbon. The latter are stabilized either by elimination of $\mathrm{N}, \mathrm{N}$-disubstituted formamide, which leads to enaminoketones 2 after subsequent opening of the dihydropyran ring, or water with the formation of adducts 3 or $\mathbf{4}$. Apparently, product $\mathbf{4}$ is also formed from intermediate $\mathbf{B}$; whereas replacement of the methoxy group with morpholine or other secondary amines in the preliminary obtained 2-methoxychroman-4-one 3a is not observed. The isolation of chromone 4 instead of the enaminoketone of type 2 from the reaction mixture occurs due to its poor solubility.

These unexpected outcomes prompted us to investigate the reaction of 3 -formylchromone with $1 \mathrm{H}$-azoles. We found that prolonged heating of an equimolar mixture of 3formylchromone $\mathbf{1}$ and imidazole or benzimidazole in methanol resulted in symmetrical 3,3'-[(azol-1-yl)methylene]bis(4H-chromen-4-ones) $\mathbf{5 a}$ and $\mathbf{5 b}$ (Scheme 5). ${ }^{13,14}$ The proposed reaction mechanism involves successive 1,4and 1,2-addition of two equivalents of azole to 3-formylchromone with the formation of adduct $\mathbf{C}$, which, on the one hand, leads to chromone $\mathbf{D}$ as a result of elimination of the azole and $N$-formylazole and, on the other hand, is con- verted into intermediate $\mathbf{E}$ due to dehydration. The subsequent Michael reaction and elimination of the azole leads to products $\mathbf{5 a}$ and $\mathbf{5 b}$. However, these outcomes only occur for the reaction with imidazole and benzimidazole. In the reaction with other $1 H$-azoles under these conditions, we obtained complex mixtures with only trace amounts of the desired products.

In conclusion, the reaction of 3-formylchromone and cyclic secondary amines in alcohols has been studied. Varying the nature of the amine, the solvent used, and the ratio of reagents affects the direction of the reaction and can lead to both 2-substituted 3-( $\mathrm{R}_{2} \mathrm{~N}$-methylene $)$ chroman-4-ones and enaminoketones as products of ring-opening. The solubility of the final product is a key factor, since it determines the position of the equilibrium.

\section{Funding Information}

This work was funded by the Russian Foundation for Basic Research (project no. 17-03-01158).

\section{Acknowledgment}

The authors are grateful to V. B. Rybakov (Moscow State University) for carrying out the X-ray structural analysis, which was fulfilled with a STOE STADI VARI PILATUS-100K diffractometer purchased by the MSU Development Program.

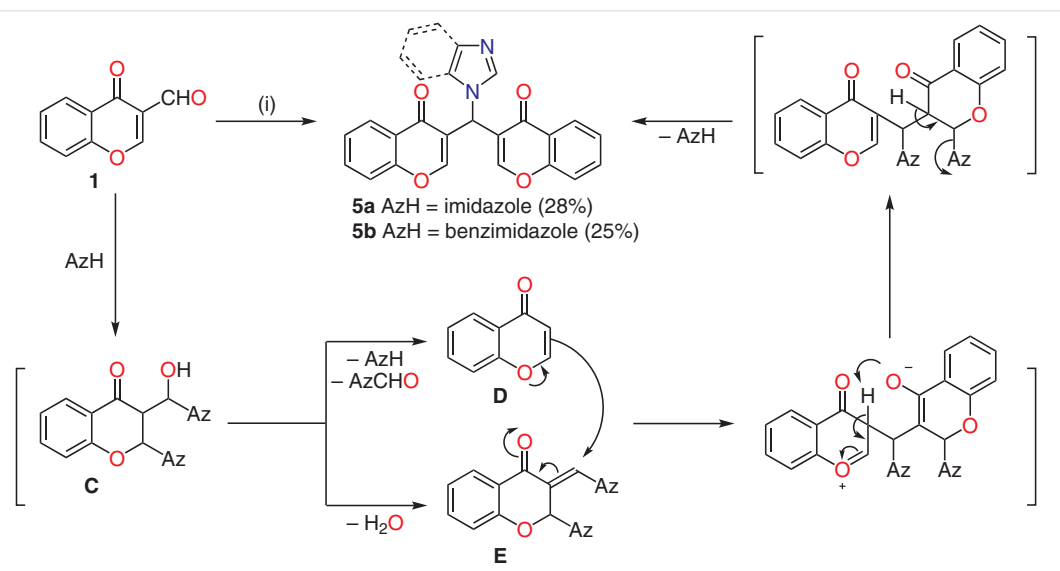

Scheme 5 Synthesis of $\mathbf{5 a}$ and $\mathbf{5 b}$. Reagents and conditions: (i) $\mathbf{1}$ ( $1 \mathrm{mmol}$ ), (benz)imidazole ( $1 \mathrm{mmol}), \mathrm{MeOH}(5 \mathrm{~mL}), \Delta, 35 \mathrm{~h}$ (for $\mathbf{5 a}$ ) or $40 \mathrm{~h}$ (for $\mathbf{5 b}$ ). 


\section{Supporting Information}

Supporting information for this article is available online at https://doi.org/10.1055/s-0039-1690339.

\section{References and Notes}

(1) For selected reviews on medicinal chemistry of chromones, see: (a) Reis, J.; Gaspar, A.; Mihazes, N.; Borges, F. J. Med. Chem. 2017, 60, 7941. (b) Silva, C. F. M.; Batista, V. F.; Pinto, D. C. G. A.; Silva, A. M. S. Expert Opin. Drug Discovery 2018, 19, 795. (c) Duan, Y.d.; Jiang, Y.-y.; Guo, F.-x.; Chen, L.-X.; Xu, L.-l.; Zhang, W.; Liu, B. Fitoterapia 2019, 135, 114. (d) Gaspar, A.; Matos, M. J.; Garrido, J.; Uriarte, E. Chem. Rev. 2014, 114, 4960. (e) Mohadeszadeh, M.; Iranshahi, M. Mini-Rev. Med. Chem. 2017, 17, 1377. (f) Sharma, S. K.; Kumar, S.; Chand, K.; Kathuria, A.; Gupta, A.; Jain, R. Curr. Med. Chem. 2011, 18, 3825. (g) Raffa, D.; Maggio, B.; Raimondi, M. V.; Plescia, F.; Daidone, G. Eur. J. Med. Chem. 2017, 142, 213.

(2) For a comprehensive review on the synthesis and biological activity of 4-chromanones, see: Emami, S.; Ghanbarimasir, Z. Eur. J. Med. Chem. 2015, 93, 539.

(3) For a seminal report on the use of 3-formylchromone as a precursor for medicines, see: Dückert, H.; Pries, V.; Khedkar, V.; Menninger, S.; Bruss, H.; Bird, A. W.; Maliga, Z.; Brockmeyer, A.; Janning, P.; Hyman, A.; Grimme, S.; Schürmann, M.; Preut, H.; Hübel, K.; Ziegler, S.; Kumar, K.; Waldmann, H. Nat. Chem. Biol. 2012, 8, 179.

(4) For selected reviews on 3-formylchromones, see: (a) Sabitha, G. Aldrichimica Acta 1996, 29, 15. (b) Ghosh, C. K.; Patra, A. J. Heterocycl. Chem. 2008, 45, 1529. (c) Ali, T. El-S.; Ibrahim, M. A.; ElGohary, N. M.; El-Kazak, A. M. Eur. J. Chem. 2013, 4, 311. (d) Ghosh, C. K.; Chakraborty, A. ARKIVOC 2015, (vi), 288. (e) Gašparová, R.; Lácová, M. Molecules 2005, 10, 937. (f) Plaskon, A. S.; Grygorenko, O. O.; Ryabukhin, S. V. Tetrahedron 2012, 68, 2743.

(5) For more recent examples, see: (a) Liao, J.-Y.; Yap, W. J.; Wu, J.; Wong, M. W.; Zhao, Y. Chem. Commun. 2017, 53, 9067. (b) Poudel, T. N.; Lee, Y. R.; Kim, S. H. Green Chem. 2015, 17, 4579. (c) Baral, E. R.; Sharma, K.; Akhtar, M. S.; Lee, Y. R. Org. Biomol. Chem. 2016, 14, 10285. (d) El-Gohary, N. M.; Ibrahim, M. A.; El-Sawy, E. R.; Abdel-fatah, N. A. J. Heterocycl. Chem. 2016, 54, 1467. (e) Gupta, S.; Khurana, J. M. Green Chem. 2017, 19, 4153.

(6) (a) Ghosh, C. K.; Khan, S. Synthesis 1981, 719. (b) Dalvi, N. R.; Shelke, S. N.; Karale, B. K.; Gill, H. C. Synth. Commun. 2007, 37, 1421. (c) Shelke, S. N.; Pawar, Y. J.; Pawar, S. B.; Gholap, S. S.; Gill, C. H. J. Indian Chem. Soc. 2011, 88, 461. (d) Halnor, V. B.; Dalvi, N. R.; Joshi, N. S.; Gill, C. H.; Karale, B. K. Indian J. Chem., Sect. B: Org. Chem. Incl. Med. Chem. 2006, 45, 288.

(7) Synthesis of Products 2-4; General Procedure

A solution of cyclic secondary amine ( $1 \mathrm{mmol}$ for $3 ; 2 \mathrm{mmol}$ for 2; $4 \mathrm{mmol}$ for 4 ) in $\mathrm{MeOH}$ (1.5 mL for 3 ) or $\mathrm{EtOH} \mathrm{(1.5} \mathrm{mL} \mathrm{for} 2$ and 4 ) was added dropwise to a stirred suspension of 3-formylchromone 1 (174 mg, $1 \mathrm{mmol}$ for 2 and 3; $348 \mathrm{mg}, 2 \mathrm{mmol}$ for 4) in $\mathrm{MeOH}$ (1.5 mL for 3 ) or EtOH (1.5 mL for 2, $4 \mathrm{~mL}$ for 4 ) in $10 \mathrm{~min}$. The resulting mixture was stirred at room temperature for $2 \mathrm{~h}$ (for $\mathbf{2}$ and $\mathbf{3}$ ) or $1 \mathrm{~h}$ (for $\mathbf{4}$ ), then was stored at $-30{ }^{\circ} \mathrm{C}$ overnight. The precipitate formed was filtered off, washed with ice-cold $\mathrm{MeOH}$, and then recrystallized from the appropriate solvent.
(8) (E)-1-(2-Hydroxyphenyl)-3-(pyrrolidin-1-yl)prop-2-en-1one (2a)

Yield: $115 \mathrm{mg}$ (53\%); yellow crystals; $\mathrm{mp} 135-137^{\circ} \mathrm{C}$ (benzene). IR (ATR): 3300-2500 (OH), 1632 (C=0), 1603, 1587, 1512, 1435, $1350,1317,1263,1219,1188,1177,1144,1103,1067,1026$, $1003,953,939,914,810,745 \mathrm{~cm}^{-1} .{ }^{1} \mathrm{H}$ NMR (400 MHz, DMSO$\left.d_{6}\right): \delta=1.79-1.86\left(\mathrm{~m}, 2 \mathrm{H}, \mathrm{CH}_{2}\right), 1.90-1.97\left(\mathrm{~m}, 2 \mathrm{H}, \mathrm{CH}_{2}\right), 3.28-$ $3.32\left(\mathrm{~m}, 2 \mathrm{H}, \mathrm{CH}_{2} \mathrm{~N}\right), 3.57-3.61\left(\mathrm{~m}, 2 \mathrm{H}, \mathrm{CH}_{2} \mathrm{~N}\right), 5.83(\mathrm{~d}, J=$ $12.1 \mathrm{~Hz}, 1 \mathrm{H}, \mathrm{CH}=\mathrm{CHN}), 6.76-6.80(\mathrm{~m}, 2 \mathrm{H}, \mathrm{Ar}), 7.29-7.34(\mathrm{~m}, 1$ $\mathrm{H}, \mathrm{Ar}), 7.84(\mathrm{~d}, J=7.8 \mathrm{~Hz}, 1 \mathrm{H}, \mathrm{Ar}), 8.04(\mathrm{~d}, J=12.1 \mathrm{~Hz}, 1 \mathrm{H}$, $\mathrm{CH}=\mathrm{CHN}), 14.49(\mathrm{~s}, 1 \mathrm{H}, \mathrm{OH}) .{ }^{13} \mathrm{C}$ NMR $\left(100 \mathrm{MHz}\right.$, DMSO- $\left.d_{6}\right): \delta=$ $25.1\left(\mathrm{CH}_{2}\right), 25.2\left(\mathrm{CH}_{2}\right), 47.8\left(\mathrm{CH}_{2} \mathrm{~N}\right), 53.0\left(\mathrm{CH}_{2} \mathrm{~N}\right), 90.7(\mathrm{CH}=\mathrm{CHN})$, $118.0(\mathrm{CH}), 118.5(\mathrm{CH}), 120.5(\mathrm{C}), 129.2(\mathrm{C}), 134.3(\mathrm{CH}), 151.7$ $(\mathrm{CH}=\mathrm{CHN}), 163.0(\mathrm{C}), 190.1(\mathrm{C}=\mathrm{O})$. Anal. Calcd for $\mathrm{C}_{13} \mathrm{H}_{15} \mathrm{NO}_{2}$ : C, 71.87; H, 6.96; N, 6.45. Found: C, 71.91; H, 7.05; N, 6.34.

\section{(E)-2-Methoxy-3-(morpholinomethylene)chroman-4-one}

(3a)

Yield: $132 \mathrm{mg}$ (48\%); light-yellow crystals; mp $140-142{ }^{\circ} \mathrm{C}$ (MeOH). IR (ATR): 1641 (C=0), 1605, 1585, 1539, 1433, 1366, 1342, 1319, 1244, 1180, 1103, 1061, 993, 953, 924, 754, 648 $\mathrm{cm}^{-1} .{ }^{1} \mathrm{H}$ NMR $\left(400 \mathrm{MHz}\right.$, DMSO- $\left.d_{6}\right): \delta=3.33(\mathrm{~s}, 3 \mathrm{H}, \mathrm{MeO})$, 3.46-3.71 (m, $\left.8 \mathrm{H}, 4 \times \mathrm{CH}_{2}\right), 6.10(\mathrm{~s}, 1 \mathrm{H}, \mathrm{H}-2), 6.99(\mathrm{~d}, J=8.2 \mathrm{~Hz}$, $1 \mathrm{H}, \mathrm{H}-8), 7.03$ (td, $J=7.6,0.9 \mathrm{~Hz}, 1 \mathrm{H}, \mathrm{H}-6), 7.40-7.45(\mathrm{~m}, 1 \mathrm{H}$, $\mathrm{H}-7), 7.59(\mathrm{~s}, 1 \mathrm{H},=\mathrm{CHN}), 7.72(\mathrm{dd}, J=7.6,1.8 \mathrm{~Hz}, 1 \mathrm{H}, \mathrm{H}-5) .{ }^{13} \mathrm{C}$ NMR (100 MHz, DMSO- $d_{6}$ ): $\delta=51.5$ (br. signal, $2 \times \mathrm{CH}_{2} \mathrm{~N}$ ), 54.9 (MeO), $66.5\left(2 \times \mathrm{CH}_{2} \mathrm{O}\right), 99.1(\mathrm{CH}-2), 100.8(\mathrm{C}-3), 118.1(\mathrm{CH}-8)$, 122.2 (CH-6), 123.5 (C-4a), 126.5 (CH-5), 134.1 (CH-7), 150.2 $(=\mathrm{CHN}), 156.2(\mathrm{C}-8 \mathrm{a}), 178.0(\mathrm{C}=\mathrm{O})$. Anal. Calcd for $\mathrm{C}_{15} \mathrm{H}_{17} \mathrm{NO}_{4}$ : C, 65.44; H, 6.22; N, 5.09. Found: C, 65.36; H, 6.17; N, 5.17.

(E)-2-Morpholino-3-(morpholinomethylene)chroman-4one (4)

Yield: $442 \mathrm{mg}$ (67\%); yellow crystals; mp $183-184^{\circ} \mathrm{C}(\mathrm{EtOH})$. IR (ATR): 1630 (C=0), 1601, 1582, 1530, 1510, 1462, 1435, 1325, 1304, 1296, 1244, 1219, 1152, 1111, 1015, 972, 943, 930, 901, $781,772,752 \mathrm{~cm}^{-1} .{ }^{1} \mathrm{H}$ NMR (400 MHz, DMSO- $\left.d_{6}\right): \delta=2.42$ (br. s, $\left.2 \mathrm{H}, \mathrm{CH}_{2} \mathrm{~N}\right), 2.71-2.76\left(\mathrm{~m}, 2 \mathrm{H}, \mathrm{CH}_{2} \mathrm{~N}\right), 3.40$ (br. s, $4 \mathrm{H}$, $\left.2 \times \mathrm{CH}_{2} \mathrm{~N}\right), 3.54-3.76\left(\mathrm{~m}, 8 \mathrm{H}, 4 \times \mathrm{CH}_{2} \mathrm{O}\right), 5.98(\mathrm{~s}, 1 \mathrm{H}, \mathrm{H}-2), 6.87-$ $6.93(\mathrm{~m}, 2 \mathrm{H}, \mathrm{H}-6,8), 7.37$ (ddd, $J=8.9,7.3,1.8 \mathrm{~Hz}, 1 \mathrm{H}, \mathrm{H}-7$ ), 7.67-7.70 (m, $2 \mathrm{H}, \mathrm{H}-5, \mathrm{NCH}=) .{ }^{13} \mathrm{C}$ NMR $\left(100 \mathrm{MHz}\right.$, DMSO- $\left.d_{6}\right): \delta$ $=47.3\left(2 \times \mathrm{CH}_{2} \mathrm{~N}\right), 52.1$ (br. signal, $\left.2 \times \mathrm{CH}_{2} \mathrm{~N}\right), 66.9\left(2 \times \mathrm{CH}_{2} \mathrm{O}\right)$, $67.0\left(2 \times \mathrm{CH}_{2} \mathrm{O}\right), 91.1(\mathrm{CH}-2), 97.8(\mathrm{C}-3), 116.6(\mathrm{CH}), 120.9(\mathrm{CH})$, $122.6(\mathrm{C}), 126.6(\mathrm{CH}), 134.4(\mathrm{CH}), 149.7(\mathrm{NCH}=), 159.8(\mathrm{C}-8 \mathrm{a})$, $178.7(\mathrm{C}=\mathrm{O})$. Anal. Calcd for $\mathrm{C}_{18} \mathrm{H}_{22} \mathrm{~N}_{2} \mathrm{O}_{4}$ : C, 65.44; $\mathrm{H}, 6.71 ; \mathrm{N}$, 8.48. Found: $\mathrm{C}, 65.51 ; \mathrm{H}, 6.66 ; \mathrm{N}, 8.35$.

(9) (a) Longobardi, M.; Bargagna, A.; Mariani, E.; Filippelli, W.; Falcone, G.; Marabese, I. Farmaco 1996, 51, 665. (b) Mosti, L.; Schenone, P.; Menozzi, G. J. Heterocycl. Chem. 1980, 17, 61.

(10) Coutts, S. J.; Wallace, T. W. Tetrahedron 1994, 50, 11755.

(11) CCDC 1936674 contains the supplementary crystallographic data for this paper. The data can be obtained free of charge from The Cambridge Crystallographic Data Centre via www.ccdc.cam.ac.uk/getstructures.

(12) (a) Maurya, N.; Singh, A. K. Dyes Pigm. 2017, 147, 484. (b) Mayuri, B.; Kavitha, P.; Basavoju, S.; Bhargavi, G.; Reddy, K. L. J. Mol. Struct. 2017, 1145, 1. (c) al-Rashida, M.; Ashraf, M.; Hussain, B.; Nagra, S. A.; Abbas, G. Bioorg. Med. Chem. 2011, 19, 3367. (d) al-Rashida, M.; Batool, G.; Sattar, A.; Ejaz, S. A.; Khan, S.; Lecka, J.; Sevigny, J.; Hameed, A.; Iqbal, J. Eur. J. Med. Chem. 2016, 115, 484. (e) El-Shaaer, H. M.; Abd-Elmonem, W. R.; Ibrahim, S. S.; Ibrahim, C. G. J. Heterocycl. Chem. 2014, 51, E167. (f) Stankovičová, H.; Lácová, M.; Gáplovský, A.; Chovancová, J.; Prónayová, N. Tetrahedron 2001, 57, 3455. 
(13) Stankovicova, H.; Gasparova, R.; Lacova, M.; Chovancova, J. Collect. Czech. Chem. Commun. 1997, 62, 781.

(14) Synthesis of $3,3^{\prime}-[(1 H$-Imidazol-1-yl)methylene $]$ bis $(4 H-$ chromen-4-one) (5a)

A mixture of 3-formylchromone 1 (174 $\mathrm{mg}, 1 \mathrm{mmol}$ ) and imidazole $(68 \mathrm{mg}, 1 \mathrm{mmol}$ ) was heated under reflux in $\mathrm{MeOH}(5 \mathrm{~mL})$ for $35 \mathrm{~h}$. The resulting solution was stored at $-30^{\circ} \mathrm{C}$ overnight, the precipitate formed was filtered and recrystallized from MeOH. Yield: $104 \mathrm{mg}$ (28\%); colorless crystals; mp $216-217^{\circ} \mathrm{C}$. IR (ATR): 1634, 1607, 1574, 1476, 1464, 1408, 1396, 1356, 1321, $1248,1217,1179,1167,1157,1136,1113,1090,1020,957,908$,
$856,824,773,756,692,660 \mathrm{~cm}^{-1} .{ }^{1} \mathrm{H}$ NMR (400 MHz, DMSO$\left.d_{6}\right): \delta=6.81(\mathrm{~s}, 1 \mathrm{H}, \mathrm{CHN}), 6.93\left(\mathrm{~s}, 1 \mathrm{H}, \mathrm{H}_{\text {imidazole }}\right), 7.32(\mathrm{~s}, 1 \mathrm{H}$, $\left.\mathrm{H}_{\text {imidazole }}\right), 7.49$ (t, $\left.J=7.6 \mathrm{~Hz}, 2 \mathrm{H}, \mathrm{Ar}\right), 7.64(\mathrm{~d}, J=8.5 \mathrm{~Hz}, 2 \mathrm{H}, \mathrm{Ar})$, 7.78-7.83 ( $\mathrm{m}, 3 \mathrm{H}, \mathrm{Ar}, \mathrm{H}-2_{\text {imidazole }}$ ), 7.99 (s, $2 \mathrm{H}, \mathrm{H}_{\alpha \text {-pyrone), }}$ ) 8.03 (d, $J=7.8 \mathrm{~Hz}, 2 \mathrm{H}, \mathrm{Ar}) .{ }^{13} \mathrm{C}$ NMR $\left(100 \mathrm{MHz}, \mathrm{DMSO}-d_{6}\right): \delta=49.3$ $(\mathrm{CHN}), 119.1(2 \times \mathrm{CH}), 119.9\left(\mathrm{CH}_{\text {imidazole }}\right), 121.8(2 \times \mathrm{C}), 123.7$ $(2 \times \mathrm{C}), 125.6(2 \times \mathrm{CH}), 126.3(2 \times \mathrm{CH}), 129.3\left(\mathrm{CH}_{\text {imidazole }}\right), 135.1$ $(2 \times \mathrm{CH}), 138.2\left(\mathrm{CH}_{\text {imidazole }}\right), 156.1\left(2 \times \mathrm{CH}_{\alpha \text {-pyrone }}\right), 156.5(2 \times \mathrm{C}-$ 8a), $175.4(2 \times \mathrm{C}=\mathrm{O})$. Anal. Calcd for $\mathrm{C}_{22} \mathrm{H}_{14} \mathrm{~N}_{2} \mathrm{O}_{4}: \mathrm{C}, 71.35 ; \mathrm{H}$, $3.81 ; \mathrm{N}, 7.56$. Found: C, 71.28; H, 3.74; N, 7.44. 